\title{
An Evaluation of English Department Coursebooks at Komar University: A Case Study
}

\author{
Kochar Ali Saeed \\ English Department, Komar University of Science and Technology, Sulaymaniyah \\ Kurdistan Region, Iraq \\ Lanya Mohammed Sabir \\ English Department, Komar University of Science and Technology \\ Sulaymaniyah, Kurdistan Region, Iraq \\ Bayar Swara Fatah \\ English Department, Komar University of Science and Technology \\ Sulaymaniyah, Kurdistan Region, Iraq
}

Received: 3/24/2021

Accepted: 5/16/2021

Published: 6/24/2021

\begin{abstract}
This research aims to give a clear image of coursebook evaluation in the English department of Komar University of Science and Technology (KUST) in Iraqi Kurdistan. The focus of this paper is to show the advantages and disadvantages of six coursebooks that are used in the English department of KUST. For this purpose, the researchers conducted interviews with the instructors and a survey with the students of these courses. These interviews and the survey show the good sides and the shortcomings of the studied coursebooks by asking different types of questions related to the contents of the books. The research took place in Fall-Winter 2019. The study results show that two-thirds of the teachers were satisfied with the coursebooks chosen to teach in the department of English to a large degree, and most of the students were satisfied with their coursebooks.

Keywords: coursebook, ELT, evaluation, interviews, Komar University, predictive evaluation, retrospective evaluation
\end{abstract}

Cite as: Saeed, K. A., Sabir, L. M., \& Fatah, B. F. (2021). An Evaluation of English Department Coursebooks at Komar University: A Case Study. Arab World English Journal, 12

(2) 169-184. DOI: https://dx.doi.org/10.24093/awej/vol12no2.12 


\section{Introduction}

This research is to provide information and evaluation of the coursebooks that have been chosen by the instructors for the English language courses. The chosen coursebooks have been used for more than four years. The students have studied them and have done many tests in these coursebooks; however, there is no proven data to show these coursebooks' significance.

Coursebooks are one of the most important guides for students during their learning process. Coursebooks open the door to more knowledge and more information. Additionally, students may find almost all the materials that have been required in a course syllabus. Therefore, it makes learning more accessible and more effective. Also, instructors choose coursebooks to follow the materials of the course outline in a productive way that makes the students arrange their studies and their knowledge according to the coursebook simultaneously. (Cunningsworth,1995.)

The importance of this study is for the indication of how coursebooks are beneficial for instructors and students at the same time. However, it can be ineffective simultaneously, and this depends on the instructor's choice.

The purpose of choosing Komar university is that most teachers are using coursebooks in English department, especially for linguistic courses. There are linguistic books that cannot be a helpful guide for students to find all of the course syllabus materials. For that reason, the results of this research will point out the useful and the useless coursebooks of the linguistic courses in this university.

The researchers attempt to discover answers for the following questions throughout this study:

- To what extent teachers think about students' level when they choose the materials for them?

- To what extent English department students are satisfied with their studying materials?

- To what extent the linguistics coursebooks' subjects are durable and contain various exercise?

This study aims to evaluate the coursebooks, whether they are useful or not. By the end of the research, coursebooks will be assessed of how helpful and beneficial they are during the courses for students and instructors at the same time. Some coursebooks provide more benefits than other coursebooks depending on the instructor's choice of the option because of the way the teachers choose a coursebook.

\section{Literature Review}

\section{The Role of Coursebooks in Language Teaching and Learning}

Tomlinson (2011) defines materials and coursebooks as the tools which the instructors or learners use to help smooth learning of a language whereas materials development refers to anything that writers, teachers and learners do to provide sources of language input and exploit those sources in ways that maximize the likelihood of intake. Hutchinson and Torres (1994, p. 315) maintained "no teaching-learning situation, it seems, is complete until it has its relevant textbook." Sheldon (1988, p.237) claimed that coursebooks "represent the visible heart of any ELT program.” 


\section{Course-book Evaluation}

There are numerous definitions and discussions from researchers with each making different claims about what course-book evaluation is. To begin, Grant (1987) stated that coursebooks open up suitable circumstances for students to acquire and practice the target language in an academic setting as an equivalent before going to real-life situations. This will ultimately help build an effective level of self-confidence in language learners as they can tell whether they are ready for real life or need more preparation to arrive at a level of satisfaction. Then, Richards and Rodgers (2001) asserted that course-books are one of the building blocks of the curriculum that is inevitable since they layout the content and outline the syllabus scope. That way, students and teachers have a system hands-on, which they can both agree on and that each can be used to arrive at their goals.

\section{Approaches to Coursebook Evaluation}

When the time comes for evaluating books, it needs time and effort to properly evaluate and an effective one. Hutchinson and Waters (1989) claimed that assessing a coursebook is done to know the good and bad sides of the book, criticizing the choice of the books chosen by a teacher. Choosing every book should go into good progress, the teachers should have all the knowledge about the book, be aware of the book contents to choose it for their courses. In order to evaluate a book, two main types of evaluation can be taken into considerations, and the types are predictive evaluation and retrospective evaluation. (Cunningsworth, 1995; Ellis, 1997). The four main types of evaluating, according to Cunningsworth and Ellis:

\section{The Predictive Evaluation}

Predictive evaluation is a type of evaluation concerned with the materials used by the teachers. When a teacher wants to decide on choosing a coursebook, they should first ask if that coursebook is available in their region or not. For this purpose, the teachers can look at other teachers' or researchers' evaluations of the books. Also, they can rely on others' evaluations of that book which they want to use. It is not necessary to be academic people; they can look for ordinary people evaluations also. Some researchers have come up with some criteria for evaluating a book or choosing a suitable book (Cunningsworth, 1984). Therefore, while deciding on a book, the criteria for evaluating the books make it easier for the teachers to select them for their courses. The requirements include learners' needs, matching the aim of the subject, and supporting the role of learning.

\section{Retrospective Evaluation}

This type of evaluation is different from the previous type; in this type, the evaluation will be on those books that have been used before. When a teacher wants to decide on a book, he or she will choose a book that has been used before, and how the book fulfills the learners needs, and the teacher decides whether the book will be used in the course that they teach or not, depending on the previous evaluation or use of the book. While teaching a course, the teacher will look at the material and the activities used in that course and decide at the end if it is good to be used again or not (Ellis, 1997). A way of carrying retrospective evaluation is by doing a micro evaluation. In micro evaluation, meaning is one of the most important points, and it evaluates the way the students react to the chosen book (Skehan, 1998). 


\section{Reasons for Coursebook Evaluation}

When it comes to the reasons for evaluating a coursebook, it can be said that there are many reasons that a book needs to be evaluated. Coursebooks provides a good source for both learner and teacher while they use them (Richards, 1993). While evaluating a coursebook, we can know if that coursebook is good or bad for the course that is studying or is this coursebook suitable for that specific level of the course learners. For choosing a book, the teachers are responsible. They should choose a book that is evaluated before and decided to be a good and effective book to be used. Therefore, evaluating a coursebook is important to make the teacher's choice easier while deciding on a book for their subject and reaching the learner's needs. The linguistics coursebooks in department of English in KUST should be evaluated to ensure their effectiveness from different perspectives.

\section{Methods and Research Design}

In this research, a survey and semi-structured interview were used to gather data from respondents. Brown and Rodgers (2002) claimed that "Surveys are any methods used to collect and identify the features, behaviors, beliefs, viewpoints, and so on of pupils, educators, supervisors, or any other individual of research interest" (p. 142).

\section{The Context of the Study}

English Department coursebooks of Komar University have been used for this study. The coursebooks are studied in several universities in Kurdistan, such as Komar University, Sulaimani University and Salahaddin University. Also, since the establishment of the English Department of Komar University in 2015, these coursebooks have been used. The coursebooks of the English department cover various elements of the spoken language. The coursebooks aim to explore the English language and literature and aim to develop writing, reading, and speaking abilities. These coursebooks have been used since 2015 and this study was conducted in 2019 .

\section{Participants}

This study aims to reveal the usefulness of the coursebooks that are in use at the Komar University, for this purpose of coursebook evaluation, the selected participants are from the Komar University. Furthermore, for this process, a survey is conducted. The respondents in this sample consisted of teachers and students. The teachers are currently teaching linguistics courses and using the coursebooks and have been picked for this analysis. Some students have been randomly chosen and engaged in the report as they participated in the process of evaluating the coursebooks. The participants, as volunteers, agreed to participate in the procedures and signed a consent form. The number of participants was 50 students, 46 females and four males. Moreover, the number of English instructors who were interviewed was three teachers, two males and one female.

Furthermore, the instructors were from the English Department of the Komar University and two of them have $\mathrm{PhD}$ and one of them has a master's degree in English language. The working experience of the instructors were various with an average of 9.5 years of experience as the participants' experience was between seven to 12 years of experience. The age of the participants was between 19 to 25 years. 


\section{Research Instruments}

In this research, the data collection is through some questionnaires and semi-structured interviews. The questionnaire is for the students and the interview is for the teachers.

\section{Questionnaire}

The questionnaire used in this research is designed by Savaş (1998). The table taken from the questionnaire has been used as it is, without any change (Appendix A). No change was made in the questionnaire. This questionnaire is used in this research because it meets the research means for evaluation of the books. This questionnaire has been used in other studies as well. One example of research that used this questionnaire is the research of Serpil and Arda (2007). This questionnaire contains 30 questions, and the items are from different categories, there are four categories that the questions divided into, and they are (layout and physical make-up, subject matter, vocabulary and structure, exercise, and activity). And the scale of the questions is from strongly disagree to agree strongly.

\section{The Semi-Structured Interview}

The semi-structured interview was adapted from Erturk (2013), in his MA research. Some words in the questions were changed to suit the research topic and need (Appendix B). The semi-structured interview was used to give the interviewer an open conversation, and a new idea can be included from the teachers' answer. Most of the questions that set for the teachers were related to the questionnaire given to the students. The teachers were asked ten questions. And the questions were about the aims of the coursebook, the example of authentic language in the coursebook, flexibility of the coursebook, using the four skills in the coursebook, the activities, interacting for using English, revision activities, vocabulary level and finally their overall opinion about the coursebook.

\section{Data Analysis}

Since no specific data analyzing tool has been used such as the Statistical Packages for Social Sciences (SPSS). A manual analysis of data has been conducted for both the questionnaires and interviews. The reason for the manual approach is that there are not as many students necessitating digital or computerized approaches. For the teacher interview questions part, the selected teachers are voice-recorded during the interview. After that, the speech is converted to text ending up with a transcript. However, where more clarifications are needed, more explanations are given. To a large degree, most of what the teacher has said in the interview is relevant and consistent with the objectives of the research paper is used as a quote from the teacher. Then similarities and differences between different teachers as well as similarities and differences among various courses that the same teacher teaches.

\section{The Questionnaire Results}

Table 1. The first data collection table is for the Syntax class or coursebook.

\begin{tabular}{|c|c|c|c|c|}
\hline Questionnaire's category & $\begin{array}{l}\text { Strongly } \\
\text { disagree }\end{array}$ & Neutral & $\begin{array}{c}\text { Strongly } \\
\text { agree }\end{array}$ & Total \\
\hline 1. Layout \& Physical Make-up & 19 & 29 & 33 & 9 \\
\hline 2. Subject Matter & 3 & 7 & 17 & 9 \\
\hline 3. Vocabulary \& Structure & 19 & 27 & 35 & 9 \\
\hline 4. Exercises \& Activities & 14 & 22 & 45 & 9 \\
\hline
\end{tabular}

ISSN: 2229-9327 
The first category is the layout and physical make-up of the coursebook. And this category includes nine questions that are about (the look, the cover, the size, the contents, the understanding, design, colors, headings, same format) of the coursebook. A total of 19 answers are strongly disagree or disagree with the question in this category. 29 answers are feeling neutral with the question, and most of the answers are 33 answers, which agree or strongly agree with the questions in this category. The second category is Subject Matter. This category includes three questions which are about (the topics, the ordering of topics, level). Three answers are strongly disagreed or disagree with the questions in this category. Seven answers are feeling neutral and 17 answers are strongly agreed or agree with the question, which is the highest range of answers. The third category is Vocabulary \& Structure. In this category, the total of 19 answers strongly disagree or disagree with the questions. 27 of the answers feel neutral, and five answers strongly agree or agree with all the questions relating to the coursebook in syntax. The fourth and last category is about the Exercise and Activity of the coursebook. In this part, there are nine questions. In these nine questions, a total of 14 students strongly disagree or disagree about the question relating to their coursebook. 22 answers say neutral, and most of the students' answers, which are 45 answers strongly agree or agree with the questions.

Table 2.The second class or coursebook evaluation is Phonetics class.

\begin{tabular}{|c|c|c|c|c|}
\hline Questionnaire's category & $\begin{array}{l}\text { Strongly } \\
\text { disagree }\end{array}$ & Neutral & $\begin{array}{c}\text { Strongly } \\
\text { agree }\end{array}$ & Total \\
\hline 1. Layout \& Physical Make-up & 6 & 8 & 31 & 5 \\
\hline 2. Subject Matter & 3 & 1 & 11 & 5 \\
\hline 3. Vocabulary and Structure & 5 & 8 & 32 & 5 \\
\hline 4. Exercises and Activates & 5 & 8 & 32 & 5 \\
\hline
\end{tabular}

The second evaluation is the phonetics coursebook. In the first category, the number of answers which disagree or strongly disagree is six. A total of eight answers state neutral about the question. And 31 answers, which are most of the answer strongly agree or agree with the questions in the layout and physical make-up category. The second category which is subject matter three answers disagree; only one of the answers is neutral. And 11 answers strongly agree or agree with the questions. In the third category, which is vocabulary and structure, five of the answers disagree or strongly disagree with the question. Eight of the answers are neutral. And 32 of the answers, which is again the majority strongly agree or agree with the question. And for the last category, which is the exercise and activity related to the coursebook they are studying. Only five answers strongly disagree or disagree with it. And eight of the answers feel neutral. Other answers, which are 32 answers strongly agree or agree with the questions.

Table 3. The third class or coursebook evaluation is Introduction to Language class.

\begin{tabular}{|c|c|}
\hline Questionnaire's category & $\begin{array}{l}\text { Strongly } \\
\text { disagree }\end{array}$ \\
\hline
\end{tabular}

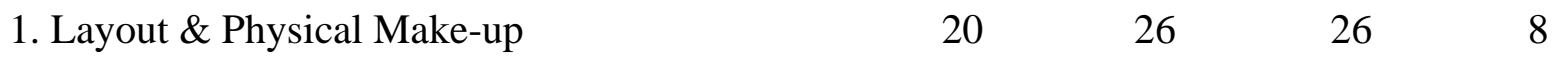

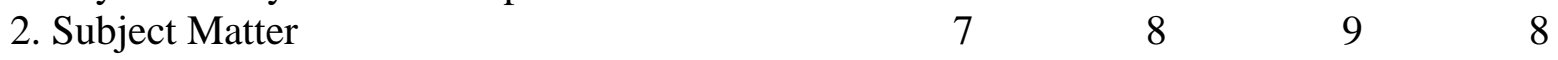

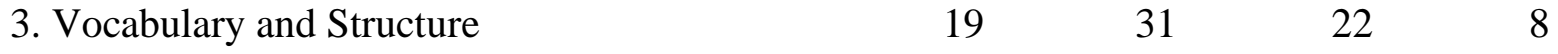

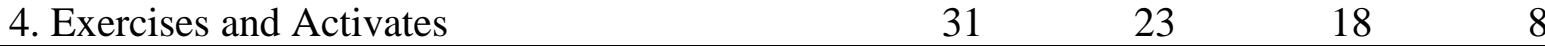

In the introduction to language class, the questionnaires are given to the students. And the result of the answering are as follows. In the first category, 20 answers strongly disagree or disagree with the questions. And twenty six answers feel neutral. And 26 answers strongly agree 
or agree with the questions. For the second category, only seven answers strongly disagree or disagree with the questions about their coursebook. Eight is neutral. And nine of the answers strongly agree or agree with the question. The third category, which is about vocabulary and structure, 19 answers disagree or strongly disagree. And 31 of the answer, which is the majority feel neutral with the questions about their coursebook. And 22 of the answers strongly agree or agree. For the last category, the majority, which is 31 answers strongly disagree or disagree with the questions related to the coursebook. And 23 of the answers feel neutral. Also, 18 answer, which is the fewer answers strongly agree or agree with the question.

Table 4. The fourth class or coursebook is Translation I class.

\begin{tabular}{lllll} 
Questionnaire's category & $\begin{array}{c}\text { Strongly } \\
\text { disagree }\end{array}$ & Neutral & $\begin{array}{c}\text { Strongly } \\
\text { agree }\end{array}$ & Total \\
1. Layout \& Physical Make-up & 32 & 24 & 16 & 8 \\
2. Subject Matter & 10 & 10 & 4 & 8 \\
3. Vocabulary and Structure & 26 & 33 & 13 & 8 \\
4. Exercises and Activates & 21 & 23 & 28 & 8 \\
\hline
\end{tabular}

The result of the translation class or coursebook evaluation is as follows. For the first categories, 32 answers strongly disagree or disagree with the question related to their coursebook. And 24 answers feel neutral. The 16 other answers strongly agree or agree with the questions. For the second category, the number of answers to strongly disagree or disagree and neutral are the same, which is 10 answers. And for strongly agree or agree the number of answers is only four answers. And for the third category 26 answers strongly disagree or disagree. 33 answers feel neutral. And 13 answers strongly agree or agree with the question related to their coursebook that they are using. In the last category 21 answers strongly disagree or disagree, 23 feel neutral. And 28 answers strongly agree or agree with the questions related to their coursebook.

Table 5. The fifth class or coursebook is Grammar III class.

\begin{tabular}{llllc}
\hline Questionnaire's category & $\begin{array}{l}\text { Strongly } \\
\text { disagree }\end{array}$ & Neutral & $\begin{array}{c}\text { Strongly } \\
\text { agree }\end{array}$ & Total \\
1. Layout \& Physical Make-up & 13 & 17 & 42 & 8 \\
2. Subject Matter & 3 & 5 & 16 & 8 \\
3. Vocabulary and Structure & 6 & 24 & 42 & 8 \\
4. Exercises and Activates & 7 & 15 & 50 & 8 \\
\hline
\end{tabular}

For the class of Grammar III, the answers of the students were as follows. For the first category, a total of 13 answers strongly disagree or disagree with the question in this category. Also, 17 answers say the questions are neutral. And most of the answers with 42 answers strongly agree or agree with the question. For the second category, only three answers strongly disagree or disagree with the question relating to their coursebook. And five answers say it is neutral. For the remaining answers, which is 16 answers strongly agree or agree with the question. In the third category, only six answers strongly disagree or disagree. 24 answers feel it is neutral. And 42 answers strongly agree or agree. And for the last category seven answers strongly disagree or disagree. And 15 answers say neutral. To strongly agree or agree, there are 50 answers, which are most of the answers to the students. 
Arab World English Journal (AWEJ) Volume 12. Number 2. June 2021

An Evaluation of English Department Coursebooks at Komar

Saeed, Sabir \& Fatah

Table 6. The sixth and last class or coursebook is Introduction to Linguistics class.

Questionnaire's category

1. Layout \& Physical Make-up

2. Subject Matter

3. Vocabulary and Structure

4. Exercises and Activates

$\begin{array}{cccc}\begin{array}{c}\text { Strongly } \\ \text { disagree }\end{array} & \text { Neutral } & \begin{array}{c}\text { Strongly } \\ \text { agree }\end{array} & \text { Total }\end{array}$

$\begin{array}{llll}8 & 20 & 26 & 6\end{array}$

$\begin{array}{llll}1 & 5 & 12 & 6\end{array}$

127

$8 \quad 20$
26

26
6

6

6

And for the last class, which is the introduction to the linguistics class, the answers are as follows. For the first category eight answers strongly disagree or disagree with the questions. 20 answers feel neutral. And 26 answers strongly agree or agree with the question related to their coursebook. In the second category of the questions, only one answer strongly disagree or disagree with the questions. Five answers feel neutral. And 12 answers strongly agree or agree with the questions. In the third category again, one answer strongly disagree or disagree. 27 answers feel neutral. And 26 of the answers strongly agree or agree with the question. And for the last category, eight answers strongly disagree or disagree. And 20 answers feel neutral with the question. And 26 answers were for the strongly agree or agree with the questions related to their coursebook they are studying in the introduction to linguistics.

\section{The result of semi-structured interviews}

The teacher interview questions comprise of ten questions covering different areas of the evaluation. There are six courses in Komar University Language Program being taught by three teachers. Some teachers teach more than one course. However, their teaching style and nature of the course have led to the fact that they shall share almost the same answer for all the courses they teach. If the teacher has given a specific answer for one course and a different answer for another, it will be highlighted and mentioned.

Question one is (Do the aims of the coursebook correspond closely with aims in the teaching program?) All three teachers responded positively. They all believe that the aims of coursebooks in all six courses are consistent with the aims set for the teaching program.

Teacher one (T1) stated, "I think that the aim of the coursebook and the major outcomes of course book match each other, and this is manifested on the level of three courses." T1 is teaching Intro to Linguistics and Intro to Language. Her answer applies to both primary coursebooks of the course. T2 said, "Yes, they have to like coursebook, and the aim should be reflecting one another usually, you have to specify your aims, and based on your aims, you design the coursebook."

Question two is (Do the aims of the coursebook correspond closely with the needs of learners?) T1's view on the matter was when you see the need of the learner is the concept of the whole might be kind of tricky to define because when you say the need of learner if you mean on the low rank, for example, it comes to matters of how they can make you solve this coursebook later on when they graduate. It may be somehow challenging to link between the learner's needs and the coursebook. But if you linked to the learners need in the English department, so yes, basically having an introduction to language serves the purpose of having an introduction to 
linguistics then you go to phonetics as one level of linguistic analysis and then you go to upper level of analysis in this case yes of course the course books are closely related to them.

Then T3 said, "Actually we had a good change by the doctor who became the head of the department. He searched a lot and rearranged the courses in the English department. One of the aspects taken into consideration was the needs of learners." T3 explained that they specialized the courses to suit the needs of students in the Kurdistan region of Iraq (KRI). T3 also said, "That is why we tried to adopt the students' needs and improve the skills to find jobs in the market."

Question three is (Does the coursebook include examples of authentic language and materials?) All three teachers responded positively to this question. T1 said, "Yes, of course especially in the case of these courses, most of the material used in the language is authentic because we usually rely on the textbooks, authors, or sometimes of the explanation of the authors. Most of the time and when we explain the different notions related to each of these fields, we rely on bringing quotations from original sources, for example, Chomsky' s books, or somebody whose writing on Chomsky so yes the material used is authentic. T3 said "If you mean today's language that is spoken by most of the world's speakers, scholars, scientists, researchers, etc. yes, we do."

Question four is (Is the coursebook flexible? Does it allow different teaching and learning styles?) In terms of teaching and learning styles, both $\mathrm{T} 1$ and $\mathrm{T} 2$ without hesitation responded positively. T2 said, "Yes, it is one of the perfect characteristics coursebook should be flexible enough that different people will learn from not only adapted one on one style or type of teaching. So, my coursebook is pretty much flexible."

T3 responded somewhat differently due to the nature of his courses. For his grammar course, he said “...for grammar, I only depend on one specific coursebook. I have, for each syllabus, two to three coursebooks. One is the primary and the other ones are secondary. The chapters of the book, the primary one, should be studied. There is no flexibility in the sense of aim for you to choose or not to choose. Then the textbook forces me to use papers, websites, read other books, even go to the other classes, etc. And for using different teaching and learning styles, yes. Every coursebook can be used academically because they are written academically.

Question five is (Are all four skills (Speaking, listening, reading, writing) adequately covered at an appropriate level?) For this question, T1 was strongly positive. She said "Of course, yes, the type of activity that is covered in the classes allows and force such variety because sometimes students engage in some sort of discussions sometimes, they write reports, they listen, and they have to read for the classes and the reports."

Then T2 and T3 explained that depending because of the curriculum, and they may not be able to cover all four skills simultaneously through the same coursebook. T2 said "It is very difficult to focus on all the forms depending on the coursebook because for some courses you have a lot of speaking and some reading, but for some other courses have reading and writing.

T3 had two different answers per course he teaches. For his grammar course, he said, "If adequately means equally, I can't say equally because it depends. Since in grammar 3, to some 
degree, they are used, but I cannot say either they are used equally or appropriately to the same level. In grammar, it is more speaking and clarification rather than writing. It is not like other courses." Similarly, for his Translation course, he said, "Actually, because this coursebook is the translation, then we don't have a lot of listening. And as well, this coursebook does not teach interpretation. It teaches translation actually." Thus, it is entirely dependent on the curriculum.

Question six is (Do the listening and speaking activities help students improve their communicative skills?) Here, T1 and T3 are, to a large extent, similarly responded negatively claiming that it is not entirely possible that their coursebooks, due to the nature of the subject, help improve communicative skills.

T2, however, though it is otherwise possible to improve communicative skills through what coursebook he uses in his classroom. He said, "Yes, pretty much they have to because once students listen and they speak, they are establishing communication so they will help students' communicative skills."

Question seven is (What opportunities exist for students to interact using English?) All three teachers happen to believe that there are plenty of opportunities for students to practice pure English. T1 said of course, all the opportunities of interaction are available in these classes because these are theoretical classes. The major point that we discuss in any of them is the point that is the subject of some discussion on reasoning. All the discussions that the students do are in the English language, Kurdish language is not allowed in classes except in Introduction to Language because it is new to the students sometimes, they may not understand a specific term or a terminology.

Then T2 said, "....inside the class would be an ideal place that students can use English properly inside the class if they want to talk and use the language properly inside the class, they have a lot of opportunities. And outside the class, it is very difficult to practice English.”.

Question eight is (Are there enough recycling and revision activities?) For this question too, all teachers are united in believing that there are plenty of revision exercises. T2 said "Yes, it is very important to make sure that students how to learn what teachers have taught they have to have some revision activities they have to like revise and reflect what they have learned."

After that, T3 said, "Yes, every time we start a class, we need to go back to the first class or the previous one, and then at the end, we need to revise. And the same thing in the coursebook." He went on to state that it includes revision of exercises and activities.

Question nine is (Is the vocabulary load of the units consistent with students' levels?) When it comes to vocabulary, T1 had some concern on the super list of terminologies assigned to students during the semester. she said "...for example for Linguistics and Phonetics, students are already familiar with the topics or terminology, but for Introduction to Language, this actually should be the case because the topics and the trend and the type of the class I mean theoretical class on linguistics as an academic discipline is new to the students. So, it is normal. [...] The only concern I have is in Linguistics because the load of the terminologies presented throughout the course is too much. 
T2 and T3, on the contrary, somewhat agreed that the vocabulary set used in the coursebooks are at an adequate level to the learners. T2 said, "Sometimes they are challenging vocabularies, but teacher's job is to simplify them and make sure that the students learn the vocabularies." Then T3 said, "Yes, because mostly these books are chosen, like this one I use in Grammar III, are for students. They are not for highly ranked academic and professional people and professors to depend on."

Finally, question ten is (What is your overall opinion about the coursebook you have been using?) Teachers' opinions varied based on the courses they teach. T1 said I think the course book for Phonetics and Linguistics so far I do not have any complaints about the coursebooks, I think they are reflecting the total materials that should be covered in the courses through when you take a look at the coursebook of Linguistics you see that it is a little bit crowded because it contains lots of terminologies and it might be some kind of a lot to the students, but still the coursebook meets the end of the class.

Then T2 said "Actually, the coursebook is essential because it is a road map, it is what teachers follow for the course but more importantly it is the implementation of how you practice what the content of the course book that is very important than the actual course book. The course books are essential to have because they show that you organize and you have a plan, but the most important thing is to follow the course books."

After that, T3 gave two different opinions per each course he teaches. For his grammar coursebook, he said, "I can say it is beneficial, but it becomes more beneficial by using other materials, and the coursebook studied should be paving the way for the other sources and coursebook to be used by students. This coursebook is not giving the last or ultimate answer to the student; it is a kind of a door opened for students to search for more information." And for his Translation course, he said, the coursebook I have been using, I can't say it is a good one. As for myself, I was not very interested in the coursebook, and I couldn't make a change in the coursebook because I didn't have that much time to make a change in the syllabus. Still, if I am going to teach next time, I will change it to remove that much theoretical or historical background about translation. I will dedicate it more for application and practical things in the classroom.

\section{Discussion of the Results}

To what extent teachers think about student's level when they choose materials for them?

When interviewing teachers at Komar University, it appeared that the teachers consider students' level to the extent that course-books fulfill the needs of learners in that specific class or semester in the English department. Teachers think that even though students may face difficulties in handling the load of material they are assigned, the teacher's job is to make sure students can comprehend the subject matter, such vocabularies and grammatical topics. In the end, teachers seemed that they are setting standards for students to be able to achieve to guarantee that learners progress with teachers' expectations and that they are ready to take on more advanced content.

One teacher stated that it might be the case that students, from time to time, find certain classes, textbooks, etc. However, in the end, it is the teacher's job to offer help, provide 
guidelines, and it makes easier for students to comprehend the subject matter. Numerous studies are claiming that it is almost impossible to find the perfect textbook that ultimately fulfills all the needs of learners. Erturk (2013) has conducted an evaluation on "Unique 6" what is presently the coursebook of grade six ELT students. He believes the coursebook does not have inspiring and interesting material to offer, and he concludes that the level of disagreement from teachers reaches its highest in a way that $75 \%$ of teachers would rather not use the coursebook next time they teach English as a foreign language. Serpil and Arda (2007) have done another research on analyzing "Let's Speak English 7" which is another EFL coursebook studied in grade seven. They deduced that although it could be effective if taught by expert teachers, the coursebook cannot be entirely suggested as the main source of study for teaching English in primary schools. If it is still used, it is recommended that the teachers put a great deal of effort into making adaptations to extract the most demanding and interesting materials and put it into proper contexts in the classroom.

\section{To what extent English department students satisfied with their studying materials?}

From the results of the questionnaire's part of the study, students have different ideas about their coursebook. The survey results in this research show that most of the students are satisfied with their coursebook. In most of the classes, the results for all the categories are positive, and the students feel good studying their coursebook. But except for one class, almost all the students do not feel good of their coursebook, and that class is "Translation" class.

In translation class, the student's answers are more strongly disagree than agree, in all the categories in the questionnaire, which is 30 questions, the total of all the students answer for all questions are 68 answers strongly disagree. This number is huge compared to other classes. Therefore, as the teacher of the "Translation" class, he claims that this book is not perfect; the students as well do not feel good studying this book in their "Translation" course. But for the rest of the five other coursebooks, generally, most of the students feel good or satisfied studying their coursebook, and they think they are getting new information or ideas.

Different from this research result, some studies have a different opinion about their coursebook. Yakhontova (2001) did a study at his university, and the study was about a book study at a Ukranian university. As a result, he found out most of the students feel happy with the book, and they suggest this book should be studied by other students as well. But in Zohrabi's (2010) research, he worked on a book named "Reading English in Action" at Tabriz university. He found out the students are not satisfied with the book, and they feel the reading part of the book is boring, and they need more communication and speaking part to be included in their coursebook.

\section{To what extent the coursebooks" subjects are durable and contain various exercises?}

Some points about the coursebook durability and the exercises are shown from both the questionnaires and semi-structured interviews. First, for answering the question that says if the coursebook subject is durable or not, most of the students from the six courses strongly agree. They all see that their coursebook's subjects are durable and easy to understand, except for one course. 
In the "Translation" class, the students feel the subjects are hard to understand. And for the exercise question part, it is also said by almost all the students that the exercise part has various types of exercises and all types of skills, like listening, speaking, reading and writing exercises. But students in "Introduction to Language" disagree with the exercise part of their book. They say their book does not have various exercises that they get to benefit from it. But mostly both the durability and exercise part of the coursebook of these six classes at Komar University are counted to be good and beneficial.

In Uyar (2014), in his research with some other teacher at Zirva university gets to a conclusion. He found out that the students in his university that he taught are not feeling good about their coursebook. From their survey results, he found out the weak points about the book are more than the strong point. And as a conclusion, they agreed to improve the weak points into strong ones, in order for the students to find the book durable and get various exercises to learn.

\section{Conclusion}

This paper aimed to find the advantages and the disadvantages of six coursebooks which have been used in the department of English of KUST since 2015. The results of the study show that two-thirds of the teachers were satisfied with the coursebooks chosen to teach in the English department to a large degree, and most of the students are satisfied with their coursebooks. However, it was noted that here and there, some teachers were not satisfied with the coursebook as well as some students, they were claiming that they were not going to use it again in the future classes but rather choose another one. Some teachers disagreed that the coursebook shall be studied as the primary textbook. Therefore, They suggested that the textbook should be integrated with other materials to fulfill the ultimate needs of learners. However, Some teachers suggested that only very up-to-date coursebooks are used and discard slightly aging textbooks. This will ensure the contents are inspiring and interesting and relevant for learners. Overall, most teachers agreed that a large percentage of the chosen coursebooks are effective and fulfill most of the students' needs. The students also agreed with the coursebook and they feel they learn. Yet again, they concluded that a textbook should not meet every necessity of learners, to make the students search for more information besides their books, but the integration of textbooks and other relevant materials will do.

\section{About the authors}

Kochar Ali Saeed: holds a master's degree in English language teaching. He has about three years of teaching experience. He has taught different English subjects, such as Academic Writing, Reading Comprehension, Grammar, Semantics, and pragmatics. His research interests include English language teaching, text book evaluation. https://orcid.org/0000-0001-6313-2041.

Lanya Sabir: https://orcid.org/0000-0002-1628-5173

Bayar Fatah : https://orcid.org/0000-0002-7235-4882. 


\section{References}

Brown, J. D., \& Rodgers, T. S. (2002). Doing second language research. New York: Oxford University Press.

Cunningsworth, A. (1984). Evaluating and Selecting EFL Teaching Materials. London: Heinemann.

Cunningsworth, A. (1995). Choosing your Coursebook. Oxford: Macmillan Heinemann ELT.

Ellis, R. (1997). The empirical evaluation of language teaching materials. ELT Journal, 51(1), 36-42. https://doi.org/10.1093/elt/51.1.36

Erturk, H. (2013). An EFL Course Book Evaluation: Unique 6, Teachers' and Students' Perspectives, (Unpublished Master's Thesis). Necmettin Erbakan University

Grant M (1987). Making the Most of Your Textbook. London: Longman. Hutchinson T, Torres E (1994). 'The Textbook as Agent of Change'. ELT Journal., 48(4).

Grant, N. (1987). Making the most of your textbook. Oxford: Heinnemann Publishers Ltd. Retrieved from http://komar.edu.iq/

Hutchinson, T., \& Torres, E. (1994). The textbook as agent of change. ELT journal, 48(4), 315328.

Hutchinson, T., \& Waters, A. (1987). English for Specific Purposes: A learner-centered approach. Cambridge: Cambridge University Press

Richards J. C. (1993). Beyond the textbook: the role of commercial materials in language teaching. RELC Journal, 24(1). https://doi.org/10.1177/003368829302400101

Richards, J., \& Rodgers, T. (2001). Approaches and methods in language teaching. Cambridge: Cambridge University Press.

Savas, P. (1998). Evaluation of Base 2, An Intermediate Coursebook for Teaching English at Bilkent University: A Case Study, (Unpublished Master's Thesis). Ankara: Bilkent University.

Serpil, T., \& Arda, A. (2007). An Analysis of English Language Teaching Coursebooks by Turkish Writers: "Let's Speak English 4" Example. International Journal of Human Sciences, 4(2), 1-18.

Sheldon, L. E. (1988). Evaluating ELT textbooks and materials. ELT journal, 42(4), 237-246.

Skehan, P. (1998). A cognitive approach to language learning. Oxford, England: Oxford University Press.

Uyar, Y. (2014). A Coursebook Evaluation Research. Mediterranean Journal of Social Sciences, 5(9), 688-696.

Yakhontova, T. (2001). Textbooks, Contexts Learners. English for Specific Purposes, 20, 397415

Zohrabi, M. (2010). Coursebook Development and Evaluation for English for General Purposes Course. English Language Teaching, 4(2), 213-222. 
Arab World English Journal (AWEJ) Volume 12. Number 2. June 2021

An Evaluation of English Department Coursebooks at Komar

Saeed, Sabir \& Fatah

\section{Appendix A: STUDENT'S QUESTIONNAIRE}

\section{Appendices}

Please answer the questions below. Indicate your answer with a TICK.

1. Sex

Male.

Female

2. Class:

0 = Strongly disagree $\quad 1=$ Disagree $\quad 2$ = Natural $\quad 3=$ Agree $\quad 4=$ Atrongly agree

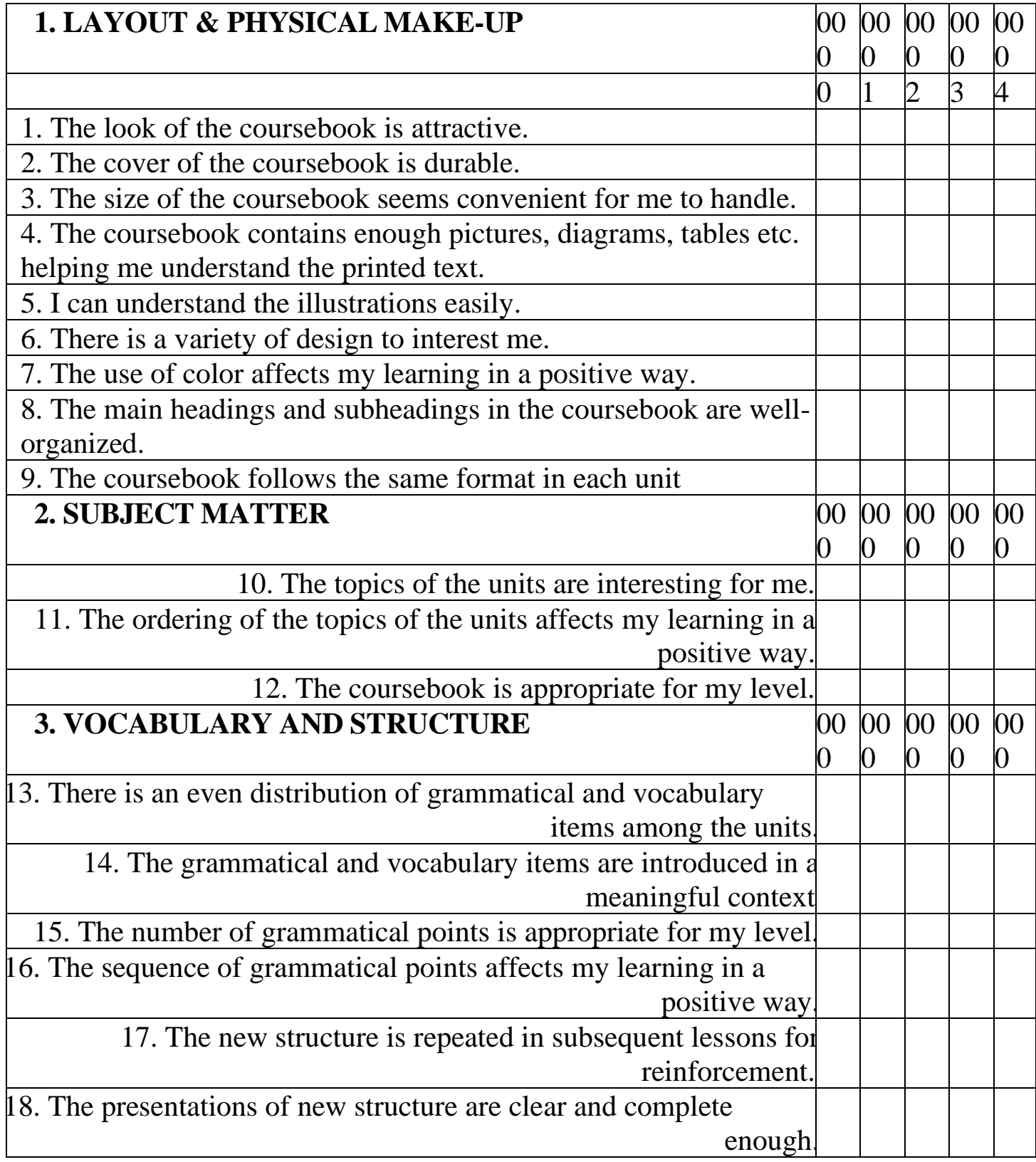


Arab World English Journal (AWEJ) Volume 12. Number 2. June 2021

An Evaluation of English Department Coursebooks at Komar

Saeed, Sabir \& Fatah

\begin{tabular}{|c|c|c|c|c|c|c|}
\hline 19. The vocabulary load seems to be reasonable for me. & & & & & & \\
\hline $\begin{array}{r}\text { 20. The new vocabulary is repeated in subsequent lessons for } \\
\text { reinforcement. }\end{array}$ & & & & & & \\
\hline $\begin{array}{r}21 . \text { The new vocabulary is integrated in varying contexts and } \\
\text { situations. }\end{array}$ & & & & & & \\
\hline 4. EXERCISES AND ACTIVITIES & 00 & 00 & 00 & 0( & & 00 \\
\hline & 0 & 0 & 0 & 0 & & 0 \\
\hline 22. There are a variety of activities in the coursebook. & & & & & & \\
\hline 23. The instructions to the activities are clear and appropriate for & & & & & & \\
\hline 24. The activities match my level in general. & & & & & & \\
\hline 25. The activities help me to understand the topic better. & & & & & & \\
\hline 26. The writing activities are adequate. & & & & & & \\
\hline 27. The speaking activities are adequate. & & & & & & \\
\hline 28. The listening activities are adequate. & & & & & & \\
\hline 29. The reading activities are adequate. & & & & & & \\
\hline 30. The language activities are adequate. & & & & & & \\
\hline
\end{tabular}

This questionnaire is designed by (Savaş 1998)

\section{Appendix B: Semi-Structured interview questions for teachers}

1. Do the aims of the course book correspond closely with the aims in the teaching program?

2. Do the aims of the course book correspond closely with the needs of learners?

3. Does the course include examples of authentic language and materials?

4. Is the course book flexible? Does it allow different teaching and learning styles?

5. Are all four skills (speaking, listening, reading, writing) adequately covered at an appropriate level?

6. Do the listening and speaking activities help students improve their communicative skills?

7. What opportunities exist for students to interact using English?

8. Are there enough recycling and revision activities?

9. Is the vocabulary load of the units consistent with students ${ }^{\text {ee levels? }}$

10. What is your overall opinion about the course book you have been using?

\section{These questions are designed by (Hilal Erturk 2013)}

